\title{
PENTINGNYA PEMANFAATAN DATA KEPENDUDUKAN DI ERA DIGITAL
}

\author{
Sri Handriana Dewi Hastuti ${ }^{1)}$ \\ ${ }^{1)}$ STMIK Syaikh Zainuddin NW Anjani-Lombok \\ e-mail: srihandriana@gmail.com ${ }^{1}$
}

\begin{abstract}
ABSTRAK
Pemanfaatan data kependudukan yang bersumber dari Dinas Dukcapil mendorong semua SKPD (Satuan Kerja Perangkat Daerah) untuk menggunakan pendekatan kebijakan satu data (one data policy). Tujuan dari pemanfaatan data ini diantaranya pemanfaatan data untuk sekolah, mengurus perijinan data, mengurus bantuan sosial semuanya harus sama dengan sumber data yang ada di Dinas Dukcapil sehingga tidak ada lagi orang yang memiliki identitas yang berbeda-beda.

Berdasarkan Permendagri Nomor 61 Tahun 2015 tentang Persyaratan, Ruang Lingkup, dan Tata Cara Pemberian Hak Akses serta Pemanfaatan NIK, Data Kependudukan, dan KTP-el, izin akses pemanfaatan data diberikan oleh Bupati/Walikota. Setelah pengajuan izin kepada Bupati/Walikota, selanjutnya dilakukan penandatangan Perjanjian Kerjasama (PKS). Selanjutnya, OPD atau intansi pelayanan publik membentuk Tim Teknis pelaksana kerjasama. Selanjutnya akses data akan diberikan sesuai dengan kebutuhan dan penggunaannya. Lembaga pengguna akses akan dimonitor oleh Bupati/Walikota melalui Dinas Dukcapil, dan secara berkala akan dilakukan pengendalian, pengawasan, dan evaluasi.
\end{abstract}

Kata Kunci: Data kependudukan, digital, pemanfaatan data kependudukan.

\begin{abstract}
Utilization of population data sourced from the Department of population and civil registration encourages all Regional Government Work Units to use a one data policy approach. The purpose of using this data includes the use of data for schools, taking care of data licensing, managing social assistance, all of which must be the same as the data sources in the Population and Civil Registration Office so that no more people have different identities.

Based on the Minister of Home Affairs Regulation No. 61 of 2015 concerning Requirements, Scope and Procedures for Granting Access Rights and Utilization of Population Identification Number, Population Data, and Electronic Resident Identity Cards, data utilization access permits are granted by the Regent / Mayor. After submitting the permit to the Regent / Mayor, then the Cooperation Agreement (PKS) is signed. Furthermore, the Regional Apparatus Organization or public service agencies form a Technical Team implementing the cooperation. Furthermore, data access will be given according to their needs and usage. The user access institution will be monitored by the Regent / Mayor through the Department of population and civil registration, and periodic control, supervision and evaluation will be conducted.
\end{abstract}

Keywords: Population data, digital, population data utilization.

\section{Pendahuluan}

$\mathrm{D}$ ata kependudukan merupakan salah satu informasi yang dibutuhkan untuk perencanaan pembangunan berkelanjutan. Pelaksanaan Sistem Informasi Administrasi Kependudukan di seluruh tanah air, tidak saja mempermudah pembuatan data kependudukan secara cepat dan akurat. Data-data yang terangkum dalam Sistem Informasi Administrasi Kependudukan ini akan dimutakhirkan dan ditertibkan Nomor Induk Kependudukannya oleh Pemerintah Pusat dan segera dicetak Kartu Tanda Penduduk Berbasis Nomor Induk Kependudukan.[1]
Database Kependudukan yang mutakhir dan akurat akan sangat mendukung dalam perencanaan kegiatan pemerintahan, pembangunan dan kemasyarakatan dimaksud. Pemutakhiran Database kependudukan tersebut dilakukan agar hasil pemutakhiran benar-benar dapat dimanfaatkan secara optimal.

Secara umum, data kependudukan tersebut digunakan untuk berbagai keperluan, yang diantaranya : (1) Pelayanan publik antara lain untuk penerbitan surat izin mengemudi, izin usaha, pelayanan wajib pajak, pelayanan perbankan, pelayanan penerbitan sertifikat tanah, asuransi, jaminan kesehatan masyarakat, dan jaminan sosial tenaga kerja. (2) Perencanaan pembangunan yakni untuk perencanaan pembangunan 
nasional, perencanaan pendidikan, perencanaan kesehatan, perencanaan tenaga kerja, dan pengentasan masyarakat dari kemiskinan. (3) Alokasi anggaran meliputi penentuan Dana Alokasi Umum (DAU) dan perhitungan potensi perpajakan. (4) Pembangunan demokrasi yaitu penyiapan Data Agregat Kependudukan per kecamatan (DAK2) dan penyiapan data Penduduk Potensial Pemilih Pemilu (DP4). (5) Penegakan hukum dan pencegahan kriminal antara lain untuk memudahkan pelacakan pelaku kriminal, mencegah perdagangan orang dan mencegah pengiriman tenaga kerja illegal.[2]

Pemanfaatan data ini untuk mendorong semua SKPD (Satuan Kerja Perangkat Daerah) untuk menggunakan pendekatan kebijakan satu data (one data policy) di mana data itu berasal dari Dinas Dukcapil. Tujuan dari pemanfaatan data ini diantaranya pemanfaatan data untuk sekolah, mengurus perijinan data, mengurus bantuan sosial semuanya harus sama dengan sumber data yang ada di Dinas Dukcapil sehingga tidak ada lagi orang yang memiliki identitas yang berbeda-beda.[3]

Informasi dan publikasi terkait dengan e-KTP, NIK, database kependudukan dan aspek terkait lainnya sudah banyak ditemukan, namun terkait dengan pemanfaatan database kependudukan di pemerintah kabupaten/kota (Pemkab/Pemkot) masih minim. Jurnal ini mengungkap bagaimana proses untuk memperoleh akses dan pemanfaan data kependudukan di lingkungan kabupaten/kota.

\section{STUDI PUSTAKA}

Secara umum data dapat diartikan sebagai kumpulan informasi yang diperoleh dari suatu pengamatan berupa angka, lambang atau sifat yang dapat memberikan gambaran tentang suatu keadaan atau persoalan. Data juga dapat didefinisikan sebagai sekumpulan informasi atau nilai yang diperoleh dari pengamatan (observasi) suatu objek. Oleh karena itu data yang baik adalah data yang bisa dipercaya kebenarannya (reliable), tepat waktu dan mencakup ruang lingkup yang luas atau bisa memberikan gambaran tentang suatu masalah secara menyeluruh merupakan data relevan.

Sedangkan kependudukan atau demografi merupakan ilmu yang mempelajari dinamika kependudukan manusia. Demografi meliputi ukuran, struktur, dan distribusi penduduk, serta bagaimana jumlah penduduk berubah setiap waktu akibat kelahiran, kematian, migrasi, serta penuaan.

Analisis kependudukan dapat merujuk masyarakat secara keseluruhan atau kelompok tertentu yang didasarkan kriteria seperti pendidikan, kewarganegaraan,agama atau etnisitas tertentu.

Dengan demikian data kependudukan adalah segala tampilan data penduduk dalam bentuk resmi maupun tidak resmi yang diterbitkan oleh badan-badan pencatatan kependudukan (pemerintah maupun non pemerintah), dalam berbagai bentuk baik angka, grafik, gambar dan lain lain.[4]

\section{METODE PENELITIAN}

Pada metode penelitian akan dijelaskan mengenai langkah-langkah dalam menyelesaikan permasalahan yang dibahas, agar dapat berjalan dengan baik. Langkahlangkah penyelesaian masalah tersebut dapat dilihat pada gambar berikut ini:

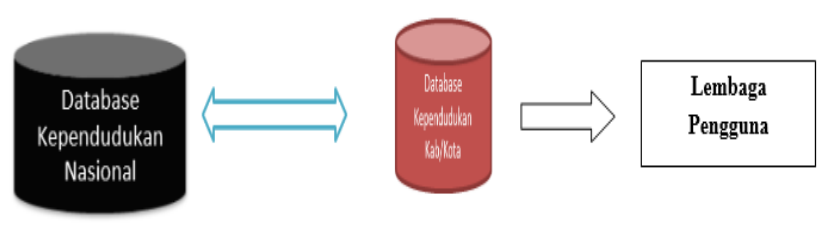

Gambar 1. Alur Penelitian

\section{HASIL DAN PEMBAHASAN}

Database kependudukan dalam SIAK (Sistem Informasi Administrasi Kependudukan ) menggunakan NIK (Nomor Induk Kependudukan) sebagai pengidentifikasi setiap record pada seluruh komponennya. Database kependudukan meliputi sejumlah item data yang lengkap tentang idenitias, pencatatan sipil, dan biometrik. Pemanfaatan database kependudukan untuk eGov dan beragam aplikasi sistem informasi di Pemkab/Pemkot sangat dimungkinkan mengingat SIAK online di setiap kecamatan langsung terhubung dengan data center kependudukan pusat di Ditjen Adminduk melalui VPN dial.

Secara khusus UU No.24 Tahun 2013 pasal 1 point 9 menyebutkan bahwa data kependudukan adalah data perseorangan dan/atau data agregat yang terstruktur sebagai hasil dari kegiatan pendaftaran penduduk dan pencatatan sipil. Dalam UU Nomor 24 Tahun 2013 tentang Administrasi Kependudukan, data dikelompokkan menjadi :

1. Data Pribadi adalah data perseorangan tertentu yang disimpan, dirawat, dan dijaga kebenaran serta dilindungi kerahasiaannya (pasal 1 point 22).

2. Database adalah kumpulan berbagai jenis data kependudukan yang tersimpan secara sistematik, terstruktur dan saling berhubungan dengan menggunakan perangkat lunak, perangkat keras dan jaringan komunikasi data (pasal 1 point 29 PP No. 37 Tahun 2007).

3. Data Kependudukan adalah data perseorangan atau data agregat yang terstruktur sebagai hasil kegiatan pendaftaran penduduk dan pencatatan sipil. [5]

Pemanfaatan data kependudukan dipahami sebagai aktivitas pemberian hak akses atas data 
kependudukan oleh Menteri Dalam Negeri kepada lembaga pengguna dalam rangka peningkatan kualitas pelayanan public, penelitian, perencanaan pembangunan, dan atau penegakan hukum. Kementerian Dalam Negeri mendelegasikan kewenangan pemanfaatan data kependudukan kepada Dirjen Dukcapil, Gubernur, dan Bupati/Walikota sesuai dengan skala kewenangannya. Ada 3 jenis pemanfaatan data penduduk, yaitu :

a. data agregat, meliputi himpunan data perseorangan yang berupa data kuantitatif dan data kualitatif,

b. pemadanan/penyandingan/pencocokan data,

c. akses data penduduk by name by address by NIK.[7]

Berdasarkan Permendagri nomor 61 tahun 2015 bahwa lingkup pemanfaatan data kependudukan adalah Nomor Induk Kependudukan (NIK), data kependudukan dan Kartu Penduduk Elektronik (Ktp-el) sedangkan data pribadi penduduk yang harus dilindungi memuat :

1. Keterangan tentang cacat fisik dan atau mental

2. Sidik jari

3. Iris mata

4. Tanda tangan

5. Elemen data lainnya yang merupakan aib sesorang.[8]

Seperti yang kita ketahui bahwa setiap warga negara memiliki catatan dan data diri yang terdokumentasi oleh setiap pemerintah daerah. Catatan dan data diri tersebut terdiri dari data kependudukan, NIK, dan KTPel. Sebagai instansi pelaksana, Dinas Dukcapil memiliki data penduduk yang lengkap dan valid. Data tersebut dibutuhkan oleh lembaga lain seperti Organisasi Perangkat Daerah (OPD), dan instansi pelayanan publik lainnya.

Berdasarkan Permendagri Nomor 61 Tahun 2015 tentang Persyaratan, Ruang Lingkup, dan Tata Cara Pemberian Hak Akses serta Pemanfaatan NIK, Data Kependudukan, dan KTP-el, izin akses pemanfaatan data diberikan oleh Bupati/Walikota. Proses pemberian ijin oleh Dirjen Dukcapil diatur di dalam Perjanjian Kerja Sama (PKS) dengan lembaga pengguna. Izin pemanfaatan data dan akses data tingkat provinsi diberikan oleh Gubernur, izin sebagaimana dimaksud sebagai persyaratan pembuatan dan pelaksanaan Perjanjian Kerja Sama antara Unit Kerja yang menangani kependudukan dan pencatatan sipil tingkat provinsi dengan lembaga pengguna. Izin pemanfaatan data dan akses data tingkat kabupaten/kota diberikan oleh $\mathrm{Bu}$ pati/Walikota, izin sebagaimana dimaksud sbagai persyaratan pembuatan dan pelaksanaan perjanjian kerja sama antara Dinas Kependudukan dan Pencatatan Sipil Kabupaten/Kota dengan lembaga pengguna tingkat kabupaten/kota.

Naskah perjanjian kerja sama sebelum ditandatangani harus dikonsultasikan terlebih dahulu kepada
Direktorat Jenderal Kependudukan dan Pencatatan Sipil serta unit kerja yang menangani kependudukan dan pencatatan sipil provinsi. Pemanfaatan NIK, data kependudukan dan KTP-el oleh lembaga pengguna tingkat kabupaten/kota, wajib menggunakan aplikasi data warehouse yang dibangun oleh Direktorat Jenderal Kependudukan dan Pencatatan Sipil Setelah pengajuan izin kepada Bupati/Walikota, selanjutnya dilakukan penandatangan Perjanjian Kerjasama (PKS). Kemudian OPD atau instansi pelayanan publik membentuk Tim Teknis pelaksana kerjasama. Selanjutnya akses data akan diberikan sesuai dengan kebutuhan dan penggunaannya. Lembaga pengguna akses akan dimonitor oleh Bupati/Walikota melalui Dinas Dukcapil, dan secara berkala akan dilakukan pengendalian, pengawasan, dan evaluasi. [6]

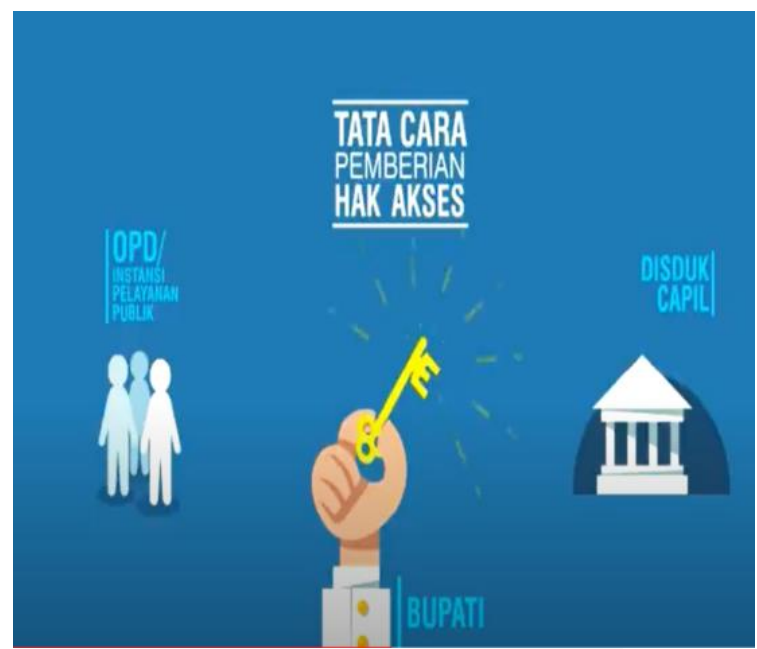

Gambar 2. Tata Cara Pemberian Hak Akses

Pemanfaatan Data Kependudukan Dukcapil Kemendagri semakin meluas dalam segala aspek kehidupan di antaranya untuk perencanaan pembangunan, pelayanan publik, dan pencegahan kriminalitas.

Contoh pemanfaatan data kependudukan :

1. Demokrasi

a. Pemilu Anggota DPR, DPRD dan DPD tahun 2014 melalui penyerahan ke KPU DAK2 dan DP4

b. Pilkada Serentak tahun 2015 melalui penyerahan ke KPU DAK2 dan DP4

2. Kepolisian

a. Mempercepat penangkapan teroris di Kab. Tangerang Selatan, 31-12-2013

b. Identifikasi jenazah yang tidak dikenali : di pandeglang 2401-2014, kasus mayat dalam koper dan lain-lain.

c. Kasus Air Asia, yang hampir sebagian besar identifikasi jenasah menggunakan data kependudukan.

3. Lainnya

a. Identifikasi dan verifikasi atas jati diri penduduk melalui akses dataware house lebih dari 23 Lembaga Pengguna (yang aktif). 
b. Dasar Penyusunan DAU

c. Integrasi dengan data TNP2K (tingkat nasional). [9]

\section{KESIMPULAN}

Berdasarkan Permendagri Nomor 61 Tahun 2015 tentang Persyaratan, Ruang Lingkup, dan Tata Cara Pemberian Hak Akses serta Pemanfaatan NIK, Data Kependudukan, dan KTP-el izin akses pemanfaatan data diberikan oleh Bupati/Walikota. Setelah pengajuan izin kepada Bupati/Walikota, selanjutnya dilakukan penandatangan Perjanjian Kerjasama (PKS). Selanjutnya, OPD atau intansi pelayanan publik membentuk Tim Teknis pelaksana kerjasama. Selanjutnya akses data akan diberikan sesuai dengan kebutuhan dan penggunaannya. Lembaga pengguna akses akan dimonitor oleh Bupati/Walikota melalui Dinas Dukcapil, dan secara berkala akan dilakukan pengendalian, pengawasan, dan evaluasi.

\section{DAFTAR PUSTAKA}

[1]https://digilib.esaunggul.ac.id/public/UEU-Master8037-bab1.pdf.

[2] http://sepang-buleleng.desa.id/index.php/first/artikel/419-Mengenal-GISA-danPentingnya-Data-Kependudukan

[3] https://www.pangkalpinangkota.go.id/zudan-menyampaikan-pentingnya-pemanfaatan-data-kependudukandi-era-digital/

[4] https://dukcapil.kalbarprov.go.id/post/memahami-tentang-pentingnya-data-kependudukan.

[5] Undang_undang No.23 Tahun 2013 tentang PERUBAHAN ATAS UNDANG-UNDANG NOMOR 23 TAHUN 2006 TENTANG ADMINISTRASI KEPENDUDUKAN.

[6]Channel Dukcapil KDN, Prosedur Pemanfaatan Data Kependudukan Oleh Perangkat Daerah dan Instansi Pelayanan Publik.2017.

[7] http://dukcapil.gunungkidulkab.go.id/mekanisme-pemanfaatan-data-kependudukan-oleh-instansilembagapengguna/.

[8] Direktorat Jenderal kependudukan dan Pencatatan Sipil Kementerian Dalam Negeri Indonesia.Implementasi Konfigurasi Baru Dalam Pemanfaatan Data Kependudukan Berdasarkan Data Terkonsolidasi dan Data Yang Dibersihkan. 2018.

[9] Fakrulloh, Zudan Arif. Pemanfaatan Data Kependudukan Untuk Mendukung Pelayanan Publik. Disampaikan dalam Konferensi Inovasi Teknologi dan Komunikasi untuk Indonesia yang ke XI dan Smart Indonesia Initiatives Forum ke I di ITB. 2015. 